\title{
Changes in Public Sector Management: Establishment of Project Management Offices - A Comparative Case Study of Lithuania and Denmark
}

\author{
Austèja Pilkaitė, Alfredas Chmieliauskas \\ ISM University of Management and Economics, \\ Arkliu str. 18, Vilnius LT-01129, Lithuania
}

DOI:10.13165/VPA-15-14-2-10

\begin{abstract}
This paper analyses an attempt to initiate an organizationaladministrative reform on the basis of experimental (pilot) project initiated by the Ministry of Economy in Lithuania which established a specialized unit - Project Management Office (PMO) - responsible for portfolio ${ }^{l}$ of programs and projects' coordination at ministerial level. The paper shortly describes types of reforms and how they can be implemented, as well as the notion of portfolio, program and project management and organizational capability to manage them, as one of the attributes of organizational maturity in project management is an existence of PMO. This article focuses on the main features of PMO and describes two qualitative case studies. Lithuanian and Danish cases are provided and differences of PMOs are analysed. The cases provide insights that the transition to portfolio, program and project management might last for decades. Although the reform did not gain the acceleration in Lithuania, the trend toward project management embedment in the public sector in Europe is evidenced and more cases of the establishment of PMO are observed.
\end{abstract}

Keywords: project management office; project, program, portfolio management; change.

Raktažodžiai: projektų valdymo skyrius; projektu, programu, portfelio valdymas; pokyčiai.

1 Portfolio management is a term used to describe methods for analysing and collectively managing a group of projects, programs and other activities based on numerous key characteristics to achieve strategic objectives of the organization. 


\section{Introduction}

Public administration and project management sciences focus on constant improvement of results (in the context of this paper - on program results). Public administration institutions are under pressure by stakeholders for performance and transparency, to make responsible, reasonable decisions regarding the right investments for taxpayers and to improve effectiveness in delivering their services. The complexity of functions performed by ministries requires applying prioritization and managerial instruments. Public sector as well faces a challenge to harmonize EU and national acquis and policies and manage EU assistance through projects. Project management often is treated as an instrument; still, it significantly contributes to the development of good public governance. Most of the strategic intervention decisions are implemented through portfolios of complex projects and programs; therefore, implementation of contemporary portfolio, program and project management methodology becomes increasingly important in the public sector.

The need for such unit like Project Management Office (PMO) in ministries came with modern governance trends and the shift towards portfolio, program and project management. As in Europe more and more allocations are based on EU funding principles, it is inevitable to adopt project management practices in order to gain more efficient and effective management $[4,15]$.

Modern project management distinguishes three key elements that are hierarchically interdependent: projects, programs and portfolios [30]. Explaining the principles of program management, in particular, it is worth paying attention to the hierarchical structure of the organizational strategy.

Each program with an organizational strategy (a specific strategic priority) bonds a bigger associated object: the strategic priority corresponds to the portfolio of initiatives; the program consists of smaller objects - projects (along with other, mostly functional, "routine" activities).

Portfolio management is a term used to describe methods for analysing and collectively managing a group of projects, programs and other activities based on numerous key characteristics to achieve strategic objectives of the organization $[23$, p. 8]. Frequently, portfolio is perceived as an ongoing strategic process of an organization covering all projects and activities aimed at strategic targets [7]. Portfolio management processes include [23]:

- Identification and categorization (of components);

- Evaluation, selection and prioritization (of components);

- Portfolio balancing;

- Authorization of components.

Organizational competencies to reach strategic objectives through a portfolio of projects and programs are measured by organizational project management maturity. Organizational project management maturity is mostly defined as the 
degree to which an organization practices organizational project management, i.e., it refers to the effectiveness of processes used within the organization $[8,26]$. Organizational maturity models are developed by PMI [5], McCormack, Ladeira and De Oliveira [21], Kruger and Johnson [17], Joly, Booth, Mittal and Shaler [14], Hartono, Wijaya and Airini [8], Rigon et al. [25], Willis and Rankin [33]. Recent international research in project management argues that project management competences directly correlate with organizational abilities of reaching the goals [31]. Organizational reform trajectory, its features and project management have clear linkages through prioritization, coordination, decision-making autonomy and portfolio balancing as well through organization scope by managing projects. The process of reform highly depends on organization maturity in project management if organization has previously dealt with projects and had any unanimous system of working with projects, whether the projects were managed individually or joint into programs and portfolios.

\begin{tabular}{|c|c|}
\hline Maturity models encompass: & Common fields in maturity models: \\
\hline Portfolio management & Management control \\
\hline Program management & Benefit management \\
\hline Project management & Organizational governance \\
\hline & Stakeholder management \\
\hline & Financial management \\
\hline & Risk management \\
\hline
\end{tabular}

\section{Figure 1. General structure of project, program and portfolio management}

Source: compiled by the authors based on CMM, OPM3, P3M3 models

One of the features of mature project-based organization is the existence of PMO. The benefits of PMO are grounded by many researchers, such as Tasic [29], Aubry, Hobbs and Thullier [3], Kwak and Dai [18], Pansini and Terzieva [22]. Still, it should be noted, based on Andersen, Henriksen and Aarseth [1], that the transition to higher maturity levels and establishing of a corporate level PMO might take around 7 years. Such long period is associated with longitudinal reform if such changes apply to a majority of institutions. The symbol of the gaining impetus in reform implementation is an establishment of PMO.

Public administration reform, as defined by Pollitt and Bouckaert [24, p. 22], is perceived as a process with plenty of ends or results. The reforms can be seen as:

- Procedural reform;

- Political reform;

- Management reform. 
Still, stability and support to implement and carry out a reform are necessary [16]. Pollitt and Bouckaert [24, p. 81] distinguished three trajectories of reform: financial, organizational and human resources. Reforms might be two-fold, either sudden or longitudinal. Sudden reforms reflect demand to move the question in the agenda and immediate decisions as well as implementation. This way of introducing reforms is often related to the top-down model of the reform, when in the public sector it is initiated by politicians or heads of institutions. Such reforms face huge resistance and the results might be not as expected or at least not of the planned scope, or at higher costs. Also, reforms can be longitudinal, when changes are applied step by step, servants inure to it and it becomes rooted into the organization or it dies without any prominent results. Such reforms might (but not necessarily) rise from bottom-up as discontent by common civil servants. A strong support for a reform is needed by management as necessary decisions might be trapped $[28,16]$. Change theories indicate that regardless of whether the changes will be strategic, structural, technological or personnel - the biggest problems usually are caused by the human factor - resistance and unwillingness to change the existing practice. One of the main tasks of change management is an appropriate communication management. Certain barriers are typical for reforms and change implementation [32]:

- Knowledge barriers (information deficit - ignorance);

- Capacity barriers (training deficit - bad execution);

- $\quad$ Lack of willingness (motivation deficit - subterfuge);

- Norm barriers (diffusion deficit - adaptation);

- $\quad$ Systemic barriers (resource deficit - inertia).

Project management has a big influence towards organizational trajectories of reform. It introduces changes not only in organizational structure by establishing $\mathrm{PMO}$, but also moving from hierarchical structure towards balanced-matrix organizational structure. Pollitt and Bouckaert [24, p. 97], describing organizational reform trajectory, distinguish the following aspects of this reform: specialization, coordination, decentralization, organizational size and scope. Features of organizational reform, such as specialization, coordination, centralization or decentralization of functions and change in scope, can be linked to project, program and portfolio management. Specialization is inconceivable without prioritization. Coordination is one of the main conjunctive functions of PMO while managing projects, programs and portfolios and assembling them into an integral system. Decentralization and centralization are directly linked to autonomy of decisionmaking of project managers and portfolio balancing in a centralized manner. Finally, scope is directly linked to the number of projects and their size. Besides, being a project-based organization might mean that scope of organization might be constantly changing. Project management has a big input towards the coordination aspect with such dimensions as management of portfolio, stakeholders, risks and communication. In the context of human resources, reform project management also impacts a step towards "post" model of civil service. 
The reform type discussed in this paper is a typical organizational reform, but as all organizational changes it cannot be implemented without affecting personnel and organizational finances. The case study discussed in Lithuanian cannot yet be called a reform, as it did not affect all public sector system, but still first steps towards gradual changes are seen and a possibility of future reforms is approaching.

The interviews were carried out in PMOs at Lithuanian MoE and Danish Commerce and Companies Agency.

\section{Project Management Office (PMO)}

PMO might have different roles, according to its functions, and also it might depend on different factors and might be established based on different reasons. PMO role might be either supportive or implementing, i.e., either this unit itself is responsible for project implementation, or it just provides a support for other units while implementing projects. Still whatever the role is, it always has a mission to focus on major program scope changes, as a goal having insights into opportunities and better achievement of institutional objectives, optimize the use of resources between all projects and manage inter-dependencies among projects, as well as maintain methodologies, standards, estimate overall risks and opportunities.

- Usually, PMO functions are the following ones [23, p. 11; 6, p. 7; 1]:

- Managing shared organizational resources dedicated to projects;

- Developing project management methodology and practices;

- Coaching, mentoring, training, giving oversight in project management;

- Monitoring compliance to standards, procedures, etc. and reporting on overall project status;

- Coordinating communication between projects and assuring project quality;

- Creating organizational process assets, project policies, templates, procedures;

- Additional functions depending on PMO: billing for services, involvement of business analysts into PMO.

To make a decision on the need of PMO, an organisation should consider the following: (1) whether it is possible to dedicate the resources to a new unit; (2) are project management standards applied in an institution; (3) whether the institution is project-based and how many projects does it have, what their size is, what main problems are in project implementation and how much they might cost; as well as (4) is there a collaboration between organizational units and the communication is ensured.

PMO functions depend on [13, p. 70] a sector an organisation performs in, if it is a private or public company, organizational size, internal or external project customers are served, level of project management maturity, matrix or non-matrix organizational structure, supportiveness of organizational culture, such as decision- 
making authority, number of projects within mandate, professionalism of project managers, age and size of a unit.

The purpose of establishing PMO describes its role either as serving internal customers (develop projects, manage internal change), which is more frequent in public organizations, or external customers (provide project outputs for outside, such as IT, construction, consulting). The difference between these two purposes is the authority, i.e., there is more power in organizations with external customers, as they are less involved into internal political systems.

PMO legitimacy and contribution to project/program performance depends on an organizational structure, as well $[27,20]$. In non-matrix organizations, the PMO role relates to the ability of decision-making. In matrix organizations, PMO might be with HR under the same manager (resources in the same organizational unit). The authority of PMO depends on a number or percentage of projects within mandate and a number of project managers within PMO. When the resources are spread in the organization, PMO involves fewer projects. Project managers working in PMO are more common in matrix organizations. Usually, PMOs are small in size - having approximately 10 persons or consulting project managers. Involvement of headquarters into PMO depends on responsibilities of PMO, i.e., is it responsible for resources or its role is only supportive - no project managers belonging inside PMO.

Hauck [9] recommends avoiding such PMO which have highly controlling functions or a strongly centralized structure. PMOs with status reporting only and decentralized structure perform better.

Also, PMOs might develop from basic PMO to standard or advanced PMO or even the center of excellence [11, p. 46]. The development encompasses broadening of PMO functions and supportiveness, the scope of control mandate, PMO autonomy. The impetus for PMO development and changes might be the following [12, p. 36]:

- External factors;

- Internal factors;

- Maturity changes;

- CEO changes;

- Work climate;

- Portfolio management and method;

- Collaboration and accountability.

Aubry, Richter, Lavoie-Tremblay and Cyr [2] in their research state that in different organizational departments, the perception of performance might be pluralistic; therefore, the contribution of PMO is essential in ensuring a united performance understanding and accompanying organizational changes.

\section{Cases of Lithuania and Denmark}

A traditional PMO was observed in The Danish Commerce and Companies Agency, which is oriented towards providing services to companies through 
e-services, e.g., registration of a new company, availability of e-forms, declarations, other important business reporting for government documents, digital signature, etc. The agency established a modernization program to achieve the main aims: create world-class business regulation, perform in risk-based inspection, provide the basis for digital reporting, less administrative burden and more social responsibility. The program started in 2009 with the goal to have the best digital systems by 2015 , which means that there is a seek for digital communication between business, citizens and the public sector. Besides, in the public sector, there are many different electronic databases; therefore, it is intended to join them into one. The main benefits of the program are delineated in Figure 2.

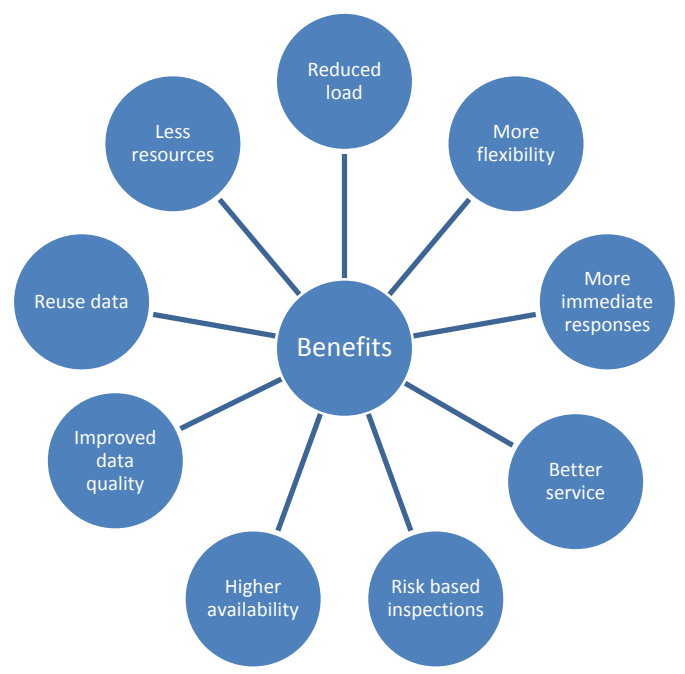

Figure 2. Benefits of the program administered by PMO in The Danish Commerce and Companies Agency

Source: The Danish Commerce and Companies Agency

The program consists of 23 projects. The program has its master-plan based on project schedules and dependencies. Project risks, stakeholders, etc. are kept separately. Project processes are based on simplified Prince2 scheme: start (initiation, internal recruitment), execution (review, status report, risk, change management, managing stage boundaries) and closure. Each process has templates and guidance. 


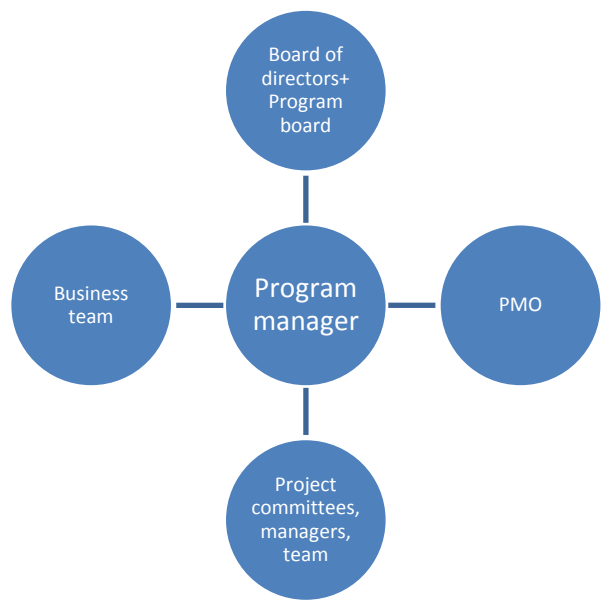

\section{Figure 3. Project administration structure and distribution of responsibilities in The Danish Commerce and Companies Agency}

Source: The Danish Commerce and Companies Agency

The board of directors consists of 5 people and they are executives in all organization. Program board, consisting of 3 persons, monitors program benefits, plans, prioritizes projects, manages risks and issues, as well as is responsible for human resources employment. Business team consists of chiefs of divisions and representatives of the board of directors. This team is responsible for communication to reference groups, as well as makes realization of benefits to employees and monthly meets the stakeholders. In the organization, a permanent PMO office is established which consists of 6 people. PMO has a function of support for project managers and the team as well as for the program board. Responsibilities of PMO are to suggest a project model for project/program manager, manage resources, communication, monitor risks, review project quality and audit reports, status reporting to boards, as well as support and coaching for project managers. Managing of resources in PMO mainly is evidenced by monitoring project time and human resources. One person in PMO is responsible for the general PMO functioning and all the others do the rest of the PMO responsibilities, even though certain functions belong to the employees inside.

Project reports are drafted using spreadsheet forms, which cover budget, quality, risks, stages and milestones, earned value in a sense of employee working time. Also, a lot of guidelines and templates are prepared, such as project contract, business cases, internal recruitments, project kick-off, risk and stakeholder analysis and management, project breakdown structures, reviews, status reports, change management and final status reports or lessons learned. 
The case of PMO in Ministry of Economy (MoE) in Lithuania is different because of its functions in the ministry and the purpose it was created for. PMO in $\mathrm{MoE}$ was established as a pilot project before deciding whether it would be beneficial to adopt and practice project management in the public sector. First of all, in this case, PMO differs from PMO in agencies or implementing institutions as ministries themselves do not implement projects unless it is their inner projects. Ministries control the portfolio in their field or public policy. They launch the programs consisting of projects and their indicators as well, control projects' results to report on policy and program performance. The PMO in MoE was established at the beginning of 2010 and it has only two-three people inside it. Initially, the unit was placed in semi-matrix organizational structure in the sense that ministerial structure is hierarchical, but still, PMO was not under any functional department and it corresponded directly to the Minister. Later on, with less support from management, the unit was incorporated into a hierarchical structure under the supervision of vice-minister responsible for programs. The idea of PMO and introduction of project management into ministerial activities in MoE are welcomed and reflect nowadays managerial trends found in other EU countries.

PMO in MoE have a number of functions consolidated into four main streams: project administration, consultation and project monitoring, preparing methods, standards and tools and delivery functions. These functions are visualised in Figure 4.

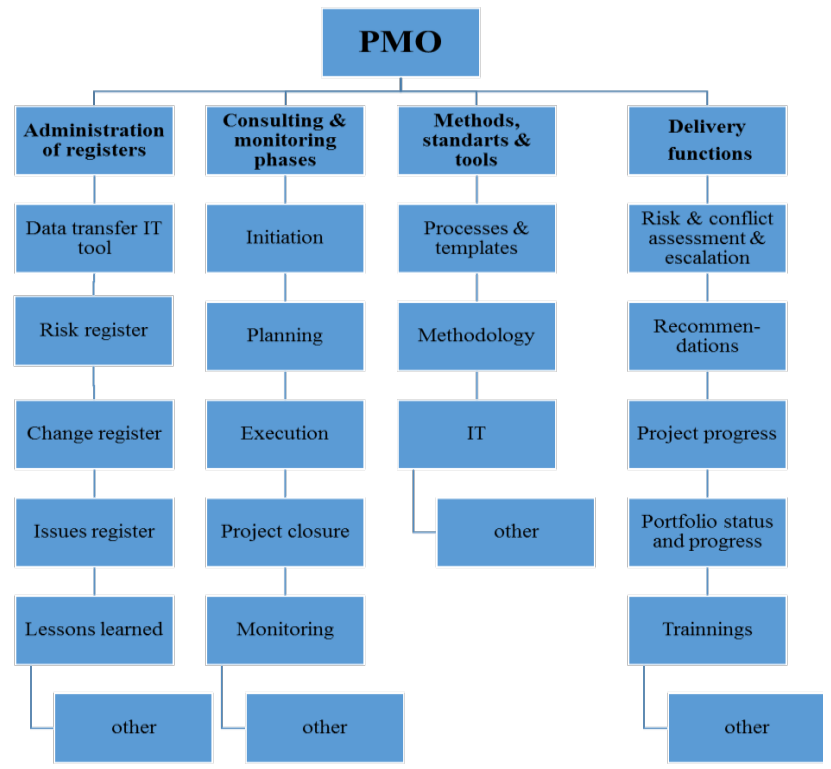

Figure 4. Functions of PMO in Ministry of Economy, Lithuania

Source: Ministry of Economy 
This unit is as well responsible for setting and controlling priorities set by the ministerial board, controlling project, providing advice for project managers as well as methodological information. Detailed functions are named below:

- develops the project management system for ministry;

- works directly with project managers and curators in the development and planning of projects and selection of specialists to project teams;

- $\quad$ provides recommendations to the project supervisors and project managers for possible ministry or its subordinate offices of human resources projects;

- provides guidance for the project management issues throughout the project cycle: initiation, planning, implementation, closure;

- controls and makes recommendations to the project implementation, reports on project problems and benefits;

- recommends the need for a project management training;

- participates in workshops and meetings related to project management at the Ministry and disseminates best practices and lessons learned outside the institution;

- monitors project progress and deadlines, risks and issues;

- prepares the interim and final project results and portfolio reports;

- performs a periodic review of the regulatory project management and development; if necessary, develops and implements new project management system elements;

- conducts the necessary procedures, methodologies and other project management related documents;

- follows news related to the global project management methodology development, the department participates in activities related events and applies innovative measures.

In MoE, PMO holds weekly meetings for Project steering committee, consisting of minister and vice-ministers. It essentially influences ministerial strategy by crystalizing ministerial priorities, linking them with programs and gathering results of projects and binding them back to strategic goals set in programs. The priorities are to foster the business environment, foster innovations, promote export and tourism, attract investments, to reform state-owned and managed companies, public procurement. The responsibilities of Project steering committee are project initiation, appointment of the project coordinator, acceptance of project application, approval of any changes in the process of implementation, analysis of results, project closure and good practice.

The PMO in MoE follows more than 100 projects, which are divided into significant ones, medium importance and minor projects. All projects are filled by MoE employees into a specially modelled JIRA database, where project's weekly reports are uploaded. The system works on a principle of traffic-light signals, where projects are earmarked by green, yellow or red (red meaning over time or over 
budget) colours. The MoE's PMO differs from traditional PMOs as it does not have any project managers inside a unit. As usually in project management, the positions are temporary until the project is over. In this case, if all project managers were employed under the PMO, the unit would manage main resources and could do the shift or replacement, as well as a more efficient cost management could be possible. This also implies that in this case, where PMO does not have project managers inside its unit, it is not involved into each project and does not bear the responsibility of project results. This indicates that PMO does not own the resources like project finances or human capital; therefore, the main focus is on prioritization and reporting, but still, methodological support and guidance for other civil servants responsible for certain projects in the field are not left aside. On the other hand, PMO introduced standard project management and reporting procedures applicable in all ministry, thus creating a common language and understanding in project management while initializing a project, planning and implementing it, monitoring and closing it.

It should be noted that PMO has initiated a celebration of international project management day, where the civil servants are invited and best project managers or project owners are nominated and get motivated. The motivation based on results is not yet implemented, but this is an aspiration of the unit.

In Lithuanian case, the pilot project of establishing a PMO has justified itself and it has been operating already for four years, still the acceleration into fully integrated reform and dissemination of practice into other ministries is not proceeding. In Lithuania's bureaucracy, it is tended to treat reforms as projects since they have a certain clear aim and timeframe. Policy is usually treated as a permanent and constant activity based on processes and functions set by legal acts. This attitude creates a resistance among civil servants and complicates the initial changes to transit into the application of project management in the public sector. When introducing a PMO in MoE in Lithuania, it faced barriers and the unit had to cope not only with the demonstration and proof of their importance and creation of added value, but also with system resistance. First of all, they had to explain what project, program and portfolio management means and why it is useful in the public sector and then move to common understanding and common project language in organization in order to handle the projects and problems inside them.

Although the reform did not gain the acceleration in Lithuania, the trend toward project management application in the public sector in Europe is evidenced and more cases of establishment of PMO are seen (e.g., the UK, the Netherlands and other Western European countries). It should be noted that one case will not change the current situation; therefore, there should be a common project language set centrally for all state institutions in order to get better results since ministries often have common projects and their functions interrelate. In such cases, it becomes much more difficult to implement the project not only due to unclear responsibilities, but also due to different understanding of how to behave in the project environment. 


\begin{tabular}{|c|c|c|}
\hline Criteria & Danish case & Lithuanian case \\
\hline $\begin{array}{l}\text { Organizational } \\
\text { structure }\end{array}$ & Matrix & $\begin{array}{l}\text { Hierarchical (project groups } \\
\text { incorporated under units) }\end{array}$ \\
\hline $\begin{array}{l}\text { Operational strategy } \\
\text { and environment }\end{array}$ & Project-based & $\begin{array}{l}\text { Partly project-based, strong } \\
\text { focus on process }\end{array}$ \\
\hline Aim of PMO & $\begin{array}{l}\text { Supporting role with the aim to } \\
\text { serve internal customers }\end{array}$ & $\begin{array}{l}\text { Supporting role with the aim } \\
\text { to serve internal customers }\end{array}$ \\
\hline Management support & Strong & Average \\
\hline Functions of PMO & $\begin{array}{l}\text { Control, consult, methodological } \\
\text { assistance, support involving } \\
\text { into certain project tasks, } \\
\text { management of shared resources }\end{array}$ & $\begin{array}{l}\text { Control, consult, } \\
\text { methodological assistance }\end{array}$ \\
\hline Projects & Internal & Internal \\
\hline $\begin{array}{l}\text { Project managers in } \\
\text { PMO }\end{array}$ & No & No \\
\hline $\begin{array}{l}\text { Project management } \\
\text { standard }\end{array}$ & Yes, adapted & No \\
\hline
\end{tabular}

\section{Figure 5. A comparative table of Danish and Lithuanian cases}

Source: compiled by the authors

To generalize, there is no one best way to arrange a PMO, as it depends on organization's structural setup, functions, goals organization wants to reach, operational strategy (whether organization implements its activities via projects or as repeating process), number of projects organization implements and an aim of establishing a PMO. To compare Danish case to Lithuanian PMOs, first of all, it should be taken into account that The Danish Commerce and Companies Agency broke down a hierarchical structure and moved towards a matrix structure a decade ago, which allowed them to eliminate bottlenecks and increase productivity more than twice. In Lithuanian case, the organisational structure of ministry is still hierarchical. Accordingly, the aim to establish a PMO at The Danish Commerce and Companies Agency was not only to control and consult, but also to get involved into projects (through communication, resources, project plans). On the contrary, Lithuania's MoE PMO does not get involved into projects and has only a consulting and controlling function. Still in both cases, the projects are internal, i.e., project results belong to organization though an impact is perceived by business, e.g., business register in Denmark, where companies can access the register, but also it is used by The Danish Commerce and Companies Agency as a responsible body registering enterprises. In the case of MoE, optimization of supervisory functions of business controlling authorities results in ease of regulatory control and supervision burden for business; simultaneously, it sets up management and administration mechanisms in MoE. So, the aim of establishing PMO sets the limits for the functions it may perform, e.g., in Denmark, functions of PMO are broader as it has more influence by getting involved into projects, and in Lithuania functions are narrower as it focuses on inner projects and more on consultation at a project level as well as 
reports for portfolio management. The status of PMO depends on an institutional operational strategy, as well. For instance, The Danish Commerce and Companies Agency restructured their work and arranged operations based on projects instead of processes (routine activities were incorporated into project work). Such shift led not only to changes in organizational structure, but also in better organizational performance. In Lithuania, the project-based approach did not gain enough support and operations were treated as a routine process. Operational strategy which focuses on process (rather than projects) measures performance in process terms and project results instead of project outcomes and impact of organizational activities. Usually, focus on a process reflects that organization's goal is not to increase performance, but rather to ensure the flow. To sum up, organizational (or even government-level) stance towards arranging activities and operations based on projects impacts the development of project supportive environment, restructuring of the organization and establishment of a PMO.

\section{Conclusions}

The reform moving towards project, program and portfolio management in the public sector, as a rule, is longitudinal as the transition to the reform goal and results might last a decade. As public policy is implemented through programs and programs consist of projects, the establishment of PMO seems to be a reasonable means to achieve effectiveness of the programmes, still it is not a common practice. PMO means recognition of project importance in an organization and it also is a reflection of organizational project management maturity. And even though in Lithuania the reform did not accelerate and did not disseminate into other ministries, still it obviously changed civil servants understanding of project management by introducing a common language. The unanimous behaviour and project-centric conduct of activities among all institutions could contribute to solving a number of cases of miscommunication and coordination problems. It would be a next step in this limp reform; therefore, full-scale managerial impetus in institutions and the government is essential to give a new boost for implementation of the reform. Granting more responsibility to PMOs and providing them an influential organizational status could substantially affect the improvement of management and program performance.

\section{References}

1. Andersen, B., Henriksen, B., and Aarseth, W. Benchmarking of Project Management Office Establishment: Extracting Best Practices. Journal of Management in Engineering. 2007, 2(23).

2. Aubry, M., Richter, M.C., Lavoie-Tremblay, M., and Cyr, G. Pluralism in PMO Performance: The Case of a PMO Dedicated to a Major Organizational Transformation. Project Management Journal. 2011, 42(6): 60-77. 
3. Aubry, M., Hobbs, B., and Thuiller, D. A New Framework for Understanding Organisational Project Management through the PMO. International Journal of Project Management. 2007, 25(4): 328-336.

4. Aubry, M., and Hobbs, B. A Fresh Look at the Contribution of Project Management to Organizational Performance. Project Management Journal. 2011, 42(1): 3-1.

5. Carnegie-Mellon, U. o. CMMI (Capability Maturity Model Integration) for Serivces. Hanscom, MA, USA: Software Engineering Institute, 2010.

6. do Valle, J. A., da Silviera e Silvia, W., and Soares, C. A. Project Management Office (PMO) - Principles in Practice. AACE International Transactions. 2008, p. 71.

7. Gorog, M. Translating Single Project Management Knowledge to Project Programs. Project Management Journal. 2011, 42(2): 17-31.

8. Hartono, B., Wijaya, D.F.N., and Arini, H.M. An Empirically Verified Project Risk Maturity Model: Evidence from Indonesian Construction Industry. International Journal of Managing Projects in Business. 2014, 7(2): 263-284.

9. Hauck, C. How to Choose the Right Project Management Office Structure for Your Organization's Culture. 2007 [interactive]. [accessed on 2013-12-01]. <www. collegiateproject.com>.

10. Helgesson, Y.Y.L., Höst, M., and Weyns, K. A Review of Methods for Evaluation of Maturity Models for Process Improvement. Journal of Software: Evolution and Process. 2012, 24(4): 436-454.

11. Hill, G. Evolving the Project Management Office: A Competency Continuum. Information Systems Management Journal. 2004, fall: 45-51.

12. Hobbs, B., Aubry, M., Muller, R., and Blomquist, T. Identifying Forces Driving PMO Changes. Project Management Journal. 2010, 4(41): 30-45.

13. Hobbs, B., and Aubry, M. An Empirically Grounded Search for a Typology of Project Management Offices. Project Management Journal. 2008, 39: 69-82.

14. Joly, B.M., Booth, M., Mittal, P., and Shaler, G. Measuring Quality Improvement in Public Health: The Development and Psychometric Testing of a QI Maturity Tool. Evaluation and Health Professions. 2012: 1-29.

15. Kassel, D. S. Managing Public Sector Projects: A Strategic Framework for Success in an Era of Downsized Government. USA: Taylor \& Francis group, 2010.

16. Kickert, W. Distinctiveness of Administrative Reform in Greece, Italy, Portugal and Spain. Common Characteristics of Context, Administrations and Reforms. Public Administration. 2011, 89(3): 801-818.

17. Kruger, C.J., and Johnson, R.D. Is There a Correlation between Knowledge Management Maturity and Organizational Performance. The Journal of Information and Knowledge Management Systems. 2011, 41(93): 265-295.

18. Kwak, Y.H., and Xiao Yi Dai, C. Assessing the Value of Project Management Offices (PMO). PMI Research Conference, 2000.

19. Maylor, H. Project Management (4th edition). Edinburgh: Person Education Limited, 2010, p. 15-35.

20. Medina, A., Müller, R., and Bredillet, C. The Fight for Resources Management: A Source of Struggles between Project Managers and Functional Managers in Matrix Organizations. In Proceedings of the European Academy of Management (EURAM) conference, June 2-4, 2011, Tallinn, Estonia. 
21. McCormack, K., Ladeira, M.B., and De Oliveira, M.P.V. Supply Chain Maturity and Performance in Brazil. Supply Chain Management: An International Journal. 2008, 13(4).

22. Pansini, F., and Terzieva M. Challenges and Benefits on the Path towards Discovering PMO: Cases from Italian Banking Sector. Procedia Technology. 2013, 9: 627-637.

23. PMI (Project Management Institute). A Guide to the Project Management Body of Knowledge (4th edition). Project Management Institute, 2008.

24. Pollitt, Ch., and Bouckaert, G. Public Management Reform. Oxford: Oxford Publishing, 2000.

25. Rigon, E.A., Westphall, C.M., dos Santos, D.R., and Westphall, C.B. A Cyclical Evaluation Model of Information Security Maturity. Information Management \& Computer Security. 2014, 22(3): 265-278.

26. Röglinger, M., Pöppelbuß, J., and Becker, J. Maturity Models in Business Process Management. Business Process Management Journal. 2012, 18(2): 328-346.

27. Singh, R., Keil, M., and Kasi, V. Identifying and Overcoming the Challenges of Implementing a Project Management Office. European Journal of Information Systems. 2009, 5(18): 409-427.

28. Skalen, P. New Public Management Reform and the Construction of Organizational Identities. International Journal of Public Sector Management. 2004, 17(3): 251-263.

29. Tasic, V. Project Management Office - Typology and Benefits. Business Informatics. 2014, 31: 173-182.

30. Turner, J.R. The Handbook of Project-Based Management: Improving the Processes for Achieving Strategic Objectives (2nd edition). McGraw-Hill, 2008.

31. Thomas, J., and Mullaly, M. Researching the Value of Project Management. Pennsylvania, USA: Project Management Institute, Inc., 2008, p. 458.

32. Thom, N., and Ritz, A. Public Management. Wiesbaden: Gabler, 2006.

33. Willis, C.J., and Rankin, J.H. The Construction Industry Macro Maturity Model (CIM3): Theoretical Underpinnings. International Journal of Productivity and Performance Management. 2012, 61(4): 382-402.

Austeja Pilkaitè, Alfredas Chmieliauskas

\section{Viešojo sektoriaus valdymo pokyčiai: projektų valdymo biurų kūrimas - lyginamoji Lietuvos ir Danijos atvejų studija}

\section{Anotacija}

Straipsnyje analizuojamas bandymas inicijuoti organizacinę-administracinę reformą, vykdant pilotinị projektą Lietuvos Ūkio ministerijoje. Šio bandymo tikslas ịkurti specializuotą padalinị - projektų valdymo biurą, kuris būtų atsakingas už portfelio, programų ir projektų koordinavimą ministerijos lygiu. Straipsnyje apžvelgiami reformų tipai ir atskleidžiama portfelio, programos ir projekto valdymo esmè bei jų valdymui reikalingi organizaciniai gebejjimai. Vienas iš organizacijos brandos bruožų yra projektų valdymo biuro egzistavimas organizacijoje. Šiame straipsnyje siekiama atskleisti projektų valdymo biuro požymius, pateikiant dvi atvejo studijas. Aptariami Lietuvos ir Danijos atvejai bei palyginami projektu valdymo biurai. Tyrimas atskleidè, kad pokyčiai pereinant prie portfelio, programų ir projektų valdymo gali trukti dešimtmetį. Nors Lietuvos atveju reforma neįvyko, tačiau Europoje stebimos tendencijos stiprinant projektų valdymą viešajame sektoriuje ir kuriantis vis daugiau projektų valdymo biurų. 
Alfredas Chmieliauskas - ISM vadybos ir ekonomikos universiteto rektorius, docentas, dèstytojas, mokslų daktaras. Buvęs Lietuvos projektų valdymo asociacijos vadovas, Tarptautinès projektų valdymo asociacijos (IPMA) Nacionalinio sertifikavimo padalinio pirmasis vertintojas, verslo ir viešosios politikos konsultantas.

E. paštas: alfredas.chmieliauskas@ism.lt

Austejja Pilkaite - ISM vadybos ir ekonomikos universiteto doktorantè.

E. paštas: austeja.pilkaite@gmail.com

Alfredas Chmieliauskas, President of ISM University of Management and Economics, Vilnius, Lithuania; PhD; Former President of the Lithuanian Project Management Association (LPVA); First Assessor of the National Certification Body authorized by the International Project Management Association (IPMA); Associated Professor; business and public policy consultant. E-mail: alfredas.chmieliauskas@ism.lt

Austejja Pilkaite, doctoral student at ISM University of Management and Economics.

E-mail: austeja.pilkaite@gmail.com

Straipsnis įteiktas redakcijai 2015 m. gegužès mėn.; recenzuotas; parengtas spaudai 2015 m. birželio mèn. 